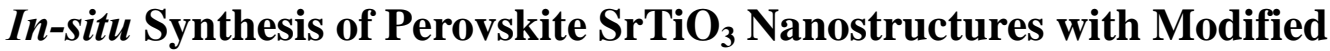 Morphology and Tunable Optical Absorption Property
}

\author{
LIU Xiao-Yuan ${ }^{1,2}$, LIU Bao-Dan ${ }^{1}$, JIANG Ya-Nan ${ }^{1}$, WANG Ke ${ }^{1,2}$, ZHOU Yang ${ }^{1,2}$, \\ YANG Bing ${ }^{1}$, ZHANG Xing-Lai ${ }^{1}$, JIANG Xin $^{1}$
}

(1. Shenyang National Laboratory for Materials Science, Institute of Metal Research, Chinese Academy of Sciences, Shenyang 110016, China; 2. School of Materials Science and Engineering, University of Science and Technology of China, Hefei 230026, China)

\begin{abstract}
As a perovskite family member, $\mathrm{SrTiO}_{3}$ shows significant applications in the fields of solar cells, photocatalysis, fuel cells and superconducting as a dependence of its crystallinity, morphology, crystal facet and optical properties. In this work, we reported an in-situ synthetic approach of $\mathrm{SrTiO}_{3}$ nanostructures with modified morphology and tunable optical absorption properties based on conventional plasma electrolytic oxidation (PEO) associated with hydrothermal method. The morphology of $\mathrm{SrTiO}_{3}$ nanostructures can be selectively modified from microcubes with smooth facets to ultrathin nanosheets by controlling the concentration of Sr source during PEO process. It is found that both $\mathrm{SrTiO}_{3}$ microcubes and $\mathrm{Sr}_{1-\delta} \mathrm{TiO}_{3}$ nanosheets are well-crystallized single crystals. UV-Vis diffuse reactance spectrum (DRS) measurement reveals that $\mathrm{Sr}_{1-\delta} \mathrm{TiO}_{3}$ nanosheets with thin thickness show obvious blue-shift of absorption edge in comparison with $\mathrm{SrTiO}_{3}$ microcubes due to the size effect. Finally, the morphology evolution and nucleation mechanism of $\mathrm{SrTiO}_{3}$ nanostructures in-situ grown on PEO film is discussed.
\end{abstract}

Key words: $\mathrm{SrTiO}_{3}$; in-situ growth; plasma electrolytic oxidation; morphology tuning; optical property

Over the past few decades, perovskite materials owning a featured $\mathrm{ABX}_{3}$ molecular formula and fascinating functional properties have received global research interest and have been widely investigated. Extensive efforts have been paid to improve the performances of these existed $\mathrm{ABX}_{3}$ materials and to seek new members in perovskite family ${ }^{[1-5]}$. In this way, the development of an efficient and accessible approach is of great importance for the nucleation design and crystallization control, as well as the rational tailoring of morphology, geometrical shape, surface characteristics and size, which have close relationship to the physicochemical properties and functional performances of these perovskite materials ${ }^{[6-7]}$.

As one of the most popular and versatile materials in perovskite family ${ }^{[8]}, \mathrm{SrTiO}_{3}$ shows significant applications in diverse fields including solar cells ${ }^{[9-10]}$, photocatalysis $^{[11-14]}$, water splitting ${ }^{[14-16]}$, fuel cells ${ }^{[17]}$, superconducting $^{[18]}$, etc. Recently, with the development of nanoscience and nanotechnology, nanostructured $\mathrm{SrTiO}_{3}$ has also received tremendous attention due to its peculiar properties and versatile functions in above-mentioned fields. So far, various $\mathrm{SrTiO}_{3}$ nanostructures including nanowires ${ }^{[12]}$, nanocubes ${ }^{[19-21]}$ and truncated octahedrons ${ }^{[22]}$ have been successfully obtained through different synthetic methods. However, the polycrystalline $\mathrm{SrTiO}_{3}$ gives rise to the existence of massive grain boundaries, generating a natural energy barrier for the electron transport, and thus deteriorates the electric property of $\mathrm{SrTiO}_{3}$. Therefore, $\mathrm{SrTiO}_{3}$ nanostructures with excellent crystal quality are definitely required. On the other hand, most of the reported $\mathrm{SrTiO}_{3}$ nanostructures are still in powder form, which will undoubtedly bring mass loss during cyclic utilization. Therefore, the fixing of $\mathrm{SrTiO}_{3}$ nanostructure with strong substrate adherence is preferable.

From the point of crystallography, $\mathrm{SrTiO}_{3}$ shows a simple cubic (s.c.) crystallographic structure and a space group Pm-3m, implying a minimum surface energy in (001) plane. For this reason, the crystallographic morphology of $\mathrm{SrTiO}_{3}$ is favorable to form cube-like structure. However, the functional properties of $\mathrm{SrTiO}_{3}$ nanostructures such as catalytic reactions are strongly

Received date: 2018-06-06; Modified date: 2018-09-12

Foundation item: National Natural Science Foundation of China (51702326, 51872296); Knowledge Innovation Program of Institute of Metal Research, Chinese Academy of Sciences (Y2NCA111A1, No.Y3NCA111A1); Youth Innovation Promotion Association, Chinese Academy of Sciences (Y4NC711171); Basic Science Innovation Program of Shenyang National Laboratory for Materials Science (2017EP05, 2017RP25)

Biography: LIU Xiao-Yuan (1990-), male, candidate of PhD. E-mail: xyliu13s@imr.ac.cn

Corresponding author: LIU Bao-Dan, professor. E-mail: baodanliu@hotmail.com; JIANG Xin, professor. E-mail: xjiang@imr.ac.cn 
dependent on its crystal facet. Considering all these points, an approach that can realize the in-situ growth of $\mathrm{SrTiO}_{3}$ nanostructures for strong substrate adherence, the crystal facet tailoring for selective catalytic reaction and superior crystal quality is generally needed for further promoting their applications in diverse fields.

As a conventional surface treatment method for enhancing metal wear resistance, plasma electrolytic oxidation (PEO) technology owns many unique advantages. It has been regarded as an ideal method to prepare metallurgical bonded film with strong adherence for cyclic utilization in some harsh environment. Furthermore, the porous PEO film can provide sufficient nucleation sites for the further in-situ growth of $\mathrm{SrTiO}_{3}$ nanostructures. In this paper, a two-step method by combining traditional PEO and hydrothermal method to in-situ synthesize $\mathrm{SrTiO}_{3}$ nanostructures on metal substrate was developed based on our previous work ${ }^{[23-25]}$. The PEO process is utilized to produce $\mathrm{Sr} / \mathrm{Ti}$ contained porous film, while the hydrothermal process enables a rational tailoring of the morphology of $\mathrm{SrTiO}_{3}$ from microcube to nanosheet. Through detailed structural characterizations, we confirmed that both the $\mathrm{SrTiO}_{3}$ microcube and $\mathrm{Sr}_{1-\delta} \mathrm{TiO}_{3}$ nanosheet are single crystals, and the two nanostructures show (100) and (110) exposed facets, respectively. It is expected that this hybrid synthetic strategy will open up more opportunities for $\mathrm{SrTiO}_{3}$ nanostructures to be used in diverse fields and can thus be further extended to the synthesis of a variety of metal oxide nanostructures with predominant advantages and promising applications.

\section{Experimental}

\subsection{PEO film fabrication}

The PEO treatment was applied to preparation of porous $\mathrm{TiO}_{2}$ film in accordance with the experiment routes of our previous work ${ }^{[23-26]}$. In a typical process, Ti substrate was used as anode, two pieces of high-purity graphite served as the counter electrode and the mixture of $\mathrm{Na}_{2} \mathrm{~B}_{4} \mathrm{O}_{7}, \mathrm{Sr}(\mathrm{AC})_{2}, \mathrm{NaOH}$ and EDTA-2Na was used as electrolyte. During a normal PEO process, the Ti substrate was immersed into the electrolyte under pulse DC power supply and charged for $12 \mathrm{~min}$. The temperature of the electrolyte was kept at around $20^{\circ} \mathrm{C}$. The current density, duty cycle and frequency were maintained at $0.13 \mathrm{~A} / \mathrm{cm}^{2}, 60 \%$ and $1000 \mathrm{~Hz}$, respectively.

\subsection{In-situ synthesis of $\mathrm{SrTiO}_{3}$ nanostructures}

In this step, porous PEO film containing $\mathrm{Sr}$ source was used as the nucleation site of $\mathrm{SrTiO}_{3}$ nanostructures. The film was vertically immersed into $15 \mathrm{~mL} \mathrm{NaOH}$ solution $(0.5 \mathrm{~mol} / \mathrm{L}, 1 \mathrm{~mol} / \mathrm{L}, 1.5 \mathrm{~mol} / \mathrm{L})$ in a Teflon-lined autoclave and heated at $180^{\circ} \mathrm{C}$ for different hydrothermal durations ( $1 \mathrm{~h}, 2 \mathrm{~h}, 4 \mathrm{~h}, 6 \mathrm{~h}, 8 \mathrm{~h})$.

\subsection{Characterizations of $\mathrm{SrTiO}_{3}$ nanostructures}

The phases and crystal structures of $\mathrm{SrTiO}_{3}$ samples were characterized by X-ray diffraction (XRD, Rigaku $\mathrm{D} / \mathrm{max} 2400)$. 3D spatial profiles of PEO film was measured via a 3D X-ray microscope (Xradia Versa XRM 500). X-ray photoelectron spectroscopy (XPS, Thermal VG/ESCALAB250) was used to obtain the binding energy of $\mathrm{SrTiO}_{3}$ samples. The morphology and composition of $\mathrm{SrTiO}_{3}$ nanostructures were characterized by a field-emission scanning electron microscopy (FE-SEM, FEI Inspect F50) equipped with a Quanta 600 Energy Dispersed X-ray spectrometer (EDS) system. The microstructure and crystallinity of $\mathrm{SrTiO}_{3}$ nanostructures were analyzed using a $200 \mathrm{kV}$ transmission electron microscopy (TEM, Tecnai G2 F20). UV-Vis diffuse reflectance spectra (DRS) of $\mathrm{SrTiO}_{3}$ nanostructures were obtained on a HITACHI U-3900 spectrophotometer.

\section{Results and discussions}

Previous work has demonstrated the merits of PEO method in obtaining metal oxide nanostructures with strong substrate adherence ${ }^{[23-27]}$. The porous film provides the nucleation sites and the precursor source for the formation of metal oxide nanostructures. In this work, the PEO film exhibits a typical porous structure comprising of numerous volcano-like channels formed during the instantaneous micro-arc discharge (Fig. S1). The porous structure is very uniform with the pore size varying from hundreds of nanometers to several micrometers. The depth of the pores can be up to $6 \mu \mathrm{m}$, which can be confirmed from the 3D X-Ray image (Fig. S2). In addition, the pores distribute homogeneously both outside and inside of the $\mathrm{TiO}_{2}$ film, providing sufficient nucleation sites for the in-situ growth of $\mathrm{SrTiO}_{3}$ nanostructures.

XRD measurement was carried out to investigate the structure/phase information of all PEO samples before (Fig. S3) and after (Fig. 1) hydrothermal treatment. The (110) (101) and (111) peaks of $\mathrm{TiO}_{2}$ in rutile phase (JCPDS no. 21-1276; $a=b=0.495 \mathrm{~nm}, c=0.296 \mathrm{~nm}$ ) at $2 \theta=27.4^{\circ}, 36.1^{\circ}$ and $41.2^{\circ}$ can be clearly distinguished. In addition, a slight trace of (101) peak at $2 \theta=25.3^{\circ}$ can also be detected, which originates from anatase phase $\mathrm{TiO}_{2}$ (JCPDS no. 21-1272; $a=b=0.379 \mathrm{~nm}, c=0.951 \mathrm{~nm}$ ). The coexistence of these two $\mathrm{TiO}_{2}$ phases in the PEO film coincides with the results of other groups ${ }^{[28]}$. The diffraction peaks at $22.4^{\circ}, 40.0^{\circ}$ and $46.5^{\circ}$ for PEO films (Fig. S3) obtained under low concentration of $\operatorname{Sr}(\mathrm{AC})_{2}$ (LSCE) match well with the (110) (111) and (200) lattice planes of $\mathrm{SrTiO}_{3}$ (JCPDS no. 35-0734; $a=b=c=0.391 \mathrm{~nm}$ ), which means that $\mathrm{SrTiO}_{3}$ has already been formed during 


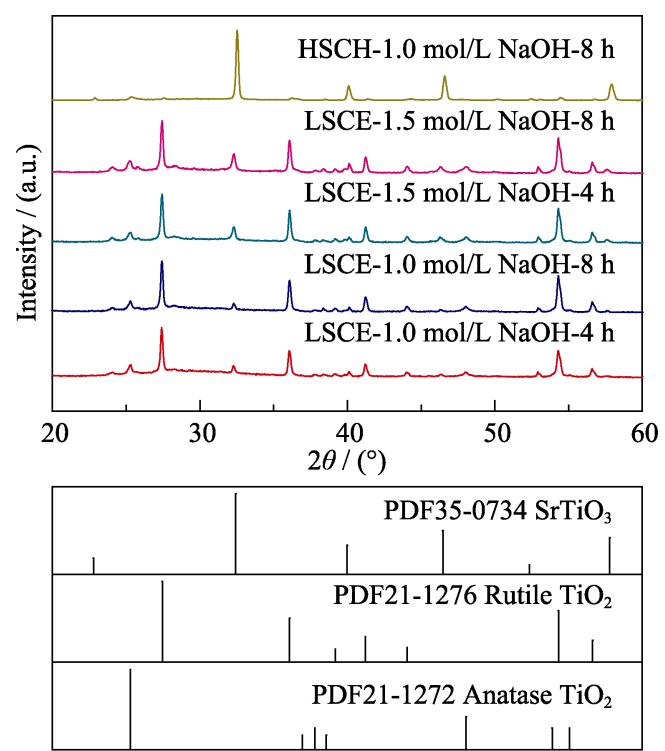

Fig. 1 XRD patterns of $\mathrm{SrTiO}_{3}$ samples prepared under different hydrothermal conditions

the PEO process. However, these peaks of $\mathrm{SrTiO}_{3}$ in PEO film disappear under high concentration of $\operatorname{Sr}(\mathrm{AC})_{2}$ (HSCE). This can be understood that the excessive $\mathrm{Sr}^{2+}$ could lead to the sedimentation of phosphate radical and cause the weakening of micro-arc discharge. As a result, the crystallization of $\mathrm{Sr}$ species in PEO film is inhibited due to the lack of discharge energy. The $\mathrm{Ti}, \mathrm{Sr}$ and $\mathrm{O}$ concentrations in PEO film are ascertained through EDS measurement (Table S1). That all samples contain a certain amount of $\mathrm{Sr}$ element although the $\mathrm{SrTiO}_{3}$ phase is not detected in the case of HSCE. A reasonable reason is that $\mathrm{SrTiO}_{3}$ exists in amorphous phase in PEO matrix. This assertion could be further verified from the diffraction dome in XRD pattern in the range of $23^{\circ}-36^{\circ}$, which is in good agreement with the formation of amorphous tungstate fabricated by PEO method ${ }^{[23-24]}$.

Hydrothermal treatment is applied on PEO film for the in-situ growth of $\mathrm{SrTiO}_{3}$ nanocrystal. Fig. 2 shows the typical morphology of $\mathrm{SrTiO}_{3}$ nanocrystals in-situ nucleated on HSCE PEO film after hydrothermal treatment. It can be seen that the surface of the PEO film is fully covered with numerous cube-like nucleus with regular crystalline facets. Each micro-cube shows smooth surface and sharp edges, and the typical size of these microcubes is $1 \mu \mathrm{m}-3 \mu \mathrm{m}$. In addition, it is also found that $\mathrm{NaOH}$ solution plays a key role in the formation of $\mathrm{SrTiO}_{3}$ nanostructures. The addition of $\mathrm{NaOH}$ in hydrothermal reaction will promote the high density of nucleation and accelerate the growth rate of $\mathrm{SrTiO}_{3}$ nanocrystals (Fig. S4) ${ }^{[12]}$, while few $\mathrm{SrTiO}_{3}$ nanocrystals can be found without the participation of $\mathrm{NaOH}$ solution (Fig. S5). As we prolong the treating time, no evident difference in size and morphology of $\mathrm{SrTiO}_{3}$ microcubes is observed
(Fig. S4(a)-(d)), indicating that the PEO film has approximately reached the precipitation-dissolution equilibrium under $0.5 \mathrm{~mol} / \mathrm{L} \mathrm{NaOH}$ solution in only $1 \mathrm{~h}$. The hydrothermal growth of $\mathrm{SrTiO}_{3}$ nanocrystals under other $\mathrm{NaOH}$ concentrations $(1.0 \mathrm{~mol} / \mathrm{L}, 1.5 \mathrm{~mol} / \mathrm{L})$ was also implemented (Fig. S6-S7). Interestingly, the morphology of these samples is quite similar only except for some traces of etching at the edges and corners of microcubes (Figure S6(a)-(c)), which is caused by the dissolution of low coordinated $\mathrm{Sr}$ and $\mathrm{Ti}$ atoms. Compositional analysis on the microcube layer using EDS measurement shows that the atomic percentages of $\mathrm{Sr}, \mathrm{Ti}$ and $\mathrm{O}$ elements are $20.77 \%, 24.16 \%$ and $55.06 \%$ (Table S2), matching well with the stoichiometric ratio of standard $\mathrm{SrTiO}_{3}$. The cubic $\mathrm{SrTiO}_{3}$ phase can also be confirmed by TEM analysis. Fig. 2(c) shows the low-magnification TEM image of $\mathrm{SrTiO}_{3}$ microcubes assembled together with all exposed crystal facets of (100) planes and $90^{\circ}$ included angle of two random adjacent planes. The HRTEM image and FFT pattern along the [110] zone axis (Fig. 2(d-e)) further indicates that the microcube is single crystal without obvious structure defect. The inter-planar spacing between neighbour lattices is $0.393 \mathrm{~nm}$ and $0.281 \mathrm{~nm}$, respectively, which matches well with the distances of (100) and (011) planes of cubic $\mathrm{SrTiO}_{3}$. All these compositional and structural results, together with XRD results (Fig. 1), have firmly demonstrated the formation of high-quality cubic $\mathrm{SrTiO}_{3}$ on the surface of porous $\mathrm{TiO}_{2}$ film and similar morphology has been observed in previous work $^{[12]}$.

When the $\mathrm{Sr}$ content in initial electrolyte was reduced, the $\mathrm{SrTiO}_{3}$ nanocrystals show quite different morphology as compared to $\mathrm{SrTiO}_{3}$ microcubes. In SEM images (Fig. 3(a)) widespread ultra-thin nanosheets take the place of $\mathrm{SrTiO}_{3}$ microcubes and fully cover the PEO film. Fig. S8 gives the SEM image of PEO sample treated in $1 \mathrm{~mol} / \mathrm{L} \mathrm{NaOH}$ for different durations. It can be seen that the size of nanosheets varies among $100 \mathrm{~nm}-200 \mathrm{~nm}$ as the reaction time is $0.5 \mathrm{~h}$ (Fig. S8(a)), and then grows to micron scale as the time extends to $1 \mathrm{~h}$ (Fig. S8(b)) and $2 \mathrm{~h}$ (Fig. S8(c)). Further increasing the treating time causes the edge curling and assembling of sheet structure (Fig. S8(d)-(e)), which is probably induced by the stress release. Adjusting the $\mathrm{NaOH}$ concentration also leads to the size evolution and morphology changing of nanosheets. Taking Fig. S8, Fig. S9 and Fig. S10 as comparisons, the sheet size shows an increasing tendency in pace with the increase of $\mathrm{NaOH}$ concentration. Through the HRTEM image (Fig. 3(d)) and corresponding FFT pattern (Fig. 3(e)), we can calculate the interlayer spacing of such nanosheet to be $0.371 \mathrm{~nm}$ along (001) plane and $0.278 \mathrm{~nm}$ along (110) plane of $\mathrm{SrTiO}_{3}$. 


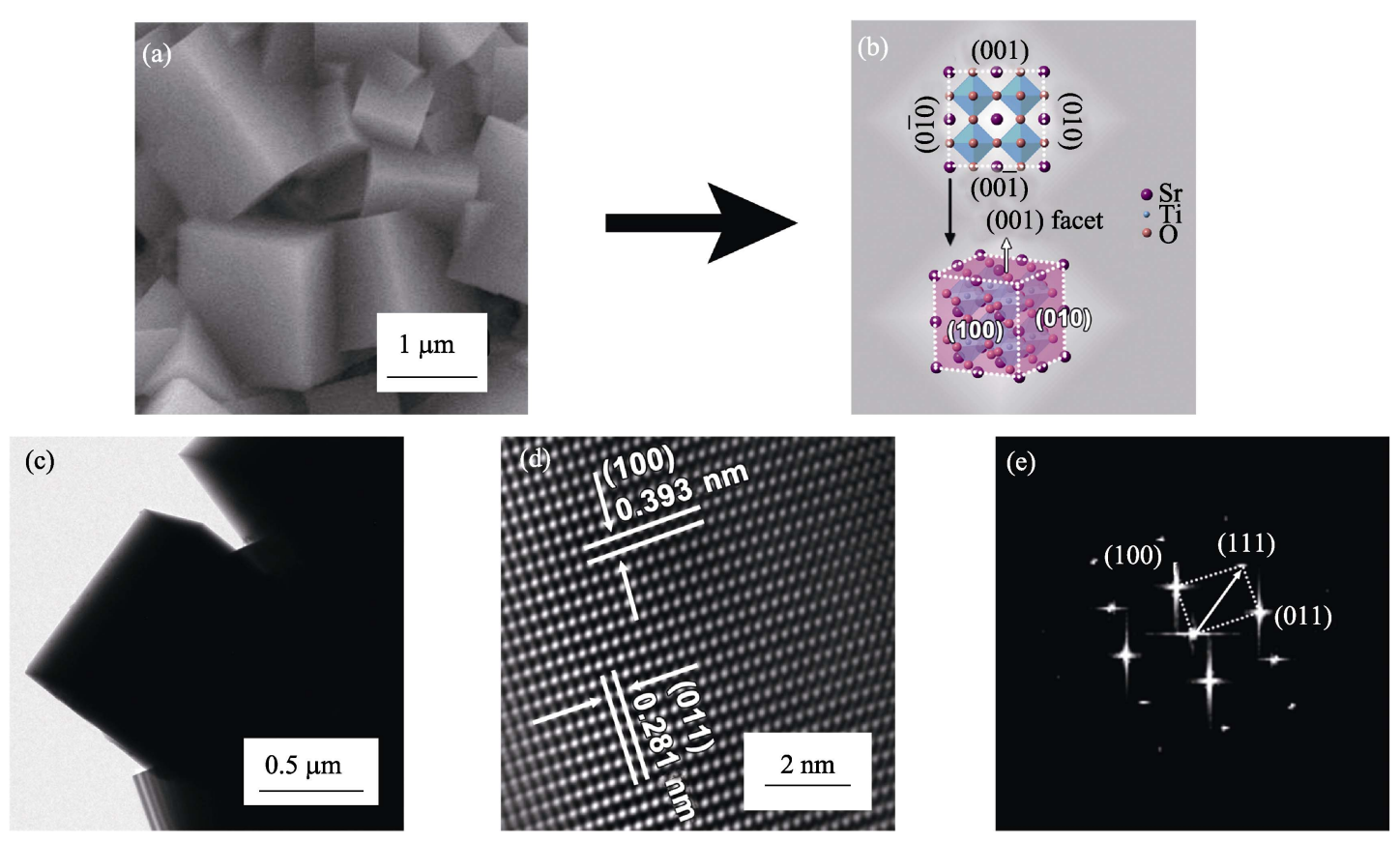

Fig. 2 (a,c) SEM image and TEM bright field image of $\mathrm{SrTiO}_{3}$ microcubes; (b) Crystallographic model of cube-like $\mathrm{SrTiO}_{3}$ nanostructure; (d,e) HRTEM image and FFT pattern of $\mathrm{SrTiO}_{3}$ microcubes
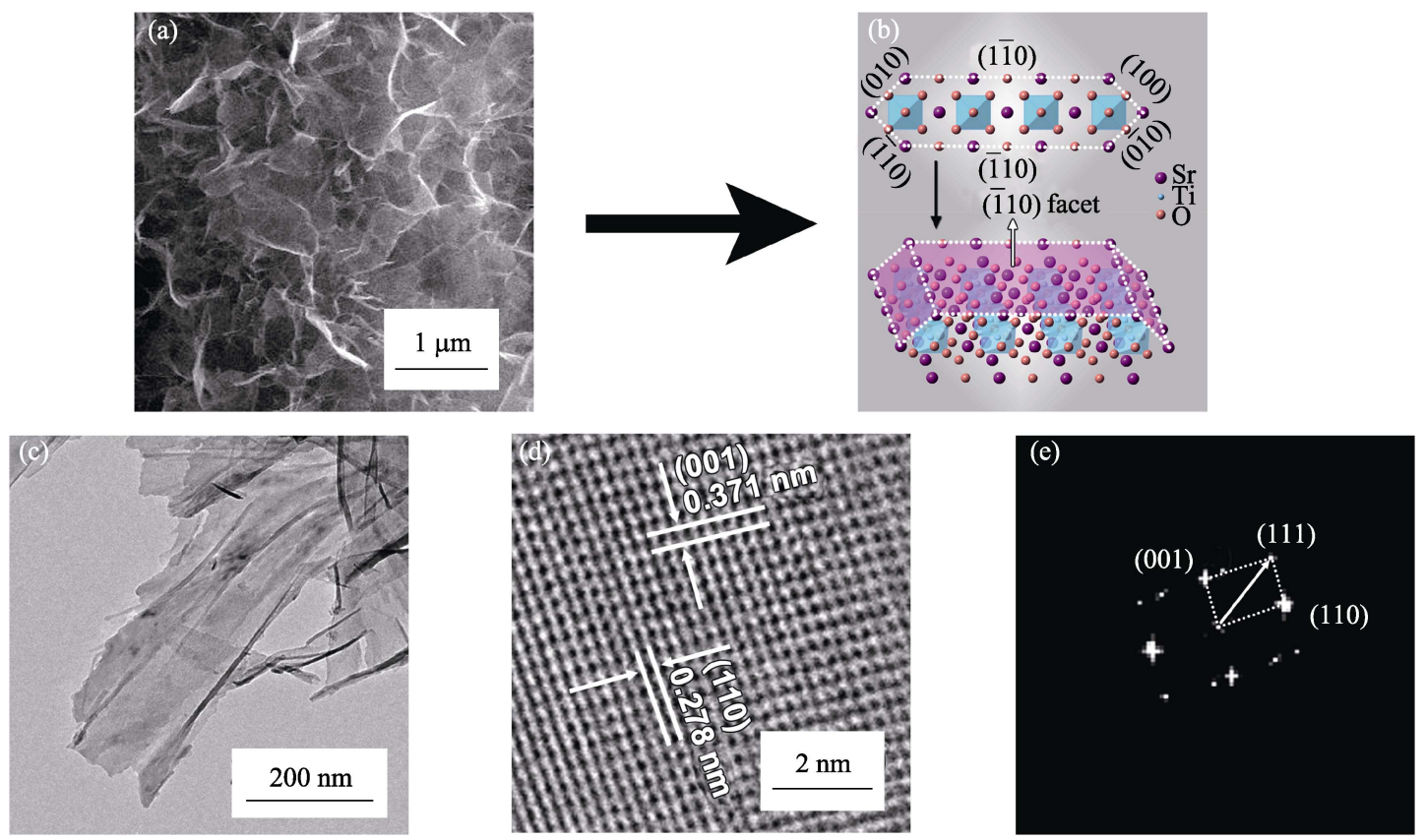

Fig. 3 (a,c) SEM image and TEM bright field image of $\mathrm{Sr}_{1-\delta} \mathrm{TiO}_{3}$ nanosheets; (b) Crystallographic model of sheet-like $\mathrm{Sr}_{1-\delta} \mathrm{TiO}_{3}$; (d,e) HRTEM image and FFT pattern of $\mathrm{Sr}_{1-\delta} \mathrm{TiO}_{3}$ nanosheets

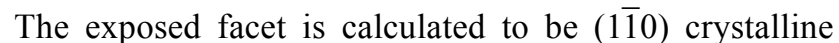
plane. Additionally, it can be seen that the crystalline quality of nanosheet is not so good as microcube (Fig. 2(d)). EDS data (Table S2) shows that the $\mathrm{Sr} / \mathrm{Ti}$ ratio of $\mathrm{SrTiO}_{3}$ nanosheets is about 0.21 , which is much smaller than the stoichiometric ratio of standard $\mathrm{SrTiO}_{3}$. In order to get more convincing conclusion, XPS element component analysis is used to collect the signals of the topmost surface of $\mathrm{SrTiO}_{3}$ nanosheets. The $\mathrm{Sr} / \mathrm{Ti}$ ratio of nanosheet is found to be around 0.31 (Table S3), which is similar to the EDS result. Thus these nanosheets can be regarded more accurately as $\mathrm{Sr}_{1-\delta} \mathrm{TiO}_{3}$. The XPS result (Fig. 4) of Sr exhibits two peaks at around $133.7 \mathrm{eV}$ and $135.4 \mathrm{eV}$ which correspond to the $3 \mathrm{~d}_{5 / 2}$ and $3 \mathrm{~d}_{3 / 2}$ electron orbit of $\mathrm{Sr}^{2+}$. Two peaks of Ti2p located at $458.0 \mathrm{eV}\left(2 \mathrm{p}_{3 / 2}\right)$ and $463.8 \mathrm{eV}\left(2 \mathrm{p}_{1 / 2}\right)$ are observed, which belong to $\mathrm{Ti}^{4+}$ in $\mathrm{SrTiO}_{3}{ }^{[12,29]}$, while no signal of $\mathrm{Ti}^{4+}$ from $\mathrm{TiO}_{2}$ is detected due to the full covering of $\mathrm{Sr}_{1-\delta} \mathrm{TiO}_{3}$ nanosheets.

Based on all the results above, the tentative formation mechanism of $\mathrm{SrTiO}_{3}$ microcubes and nanosheets is 

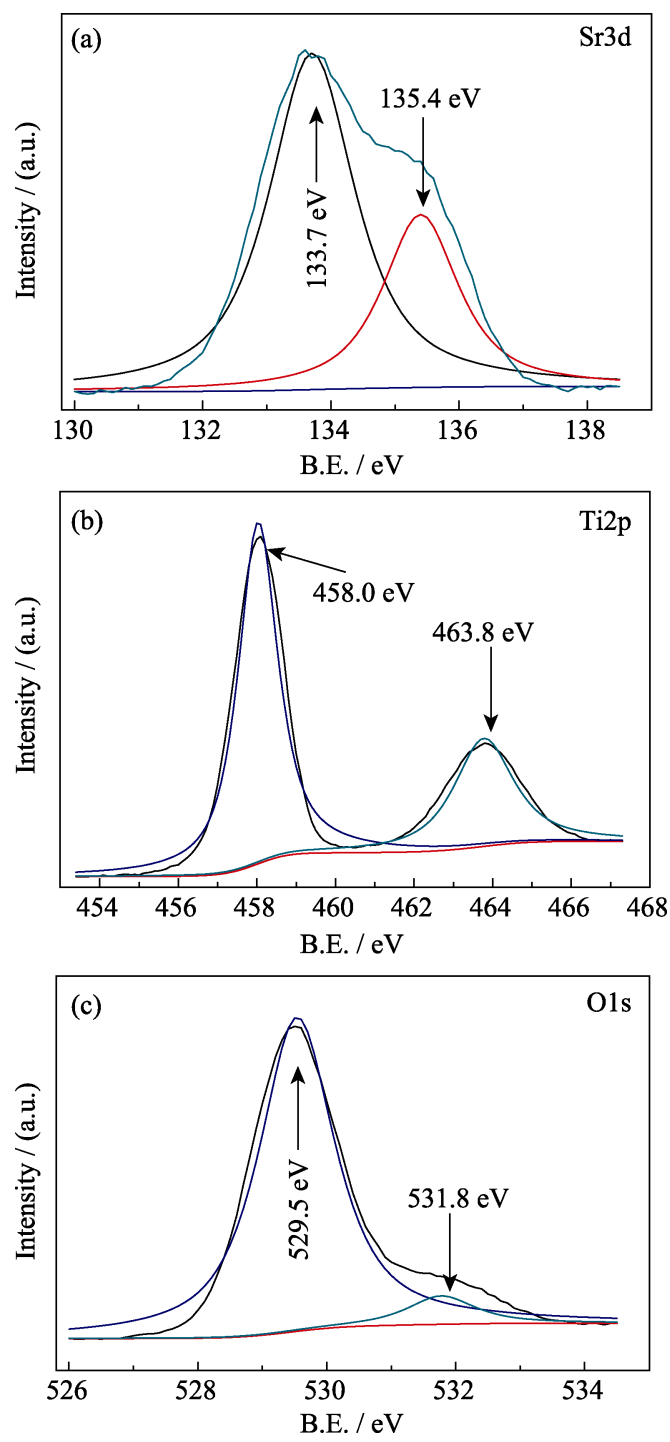

Fig. 4 XPS spectra of (a) Sr3d, (b) Ti2p and (c) O1s of $\mathrm{Sr}_{1-\delta} \mathrm{TiO}_{3}$ nanosheets prepared under $1.0 \mathrm{~mol} / \mathrm{L} \mathrm{NaOH}$ solution for $8 \mathrm{~h}$

proposed (Fig. 5). The PEO film serves as both substrate and precursor for the nucleation of $\mathrm{SrTiO}_{3}$ nanocrystals and the $\mathrm{Sr} / \mathrm{Ti}$ source for hydrothermal reaction. During hydrothermal process, $\mathrm{Sr} / \mathrm{Ti}$ species in the PEO film can quickly dissolve under elevated temperature in alkaline environment, then the released $\mathrm{Sr}^{2+}$ and $\mathrm{Ti}^{4+}$ species suf- fer from a hydrolysis process. The hydrolysis of $\mathrm{Ti}^{4+}$ is very quick ${ }^{[30]}$, leading to the rapid formation of $\left[\mathrm{Ti}(\mathrm{OH})_{y}\right]^{4-y}$, which is further aggregated into colloid species $\left\{\left[\mathrm{Ti}(\mathrm{OH})_{y}\right]^{4-y}\right\}_{n} .\left[\mathrm{Sr}(\mathrm{OH})_{x}\right]^{2-x}$ are also formed at the same time. In alkaline condition, $\left[\mathrm{Sr}(\mathrm{OH})_{x}\right]^{2-x}$ will break the Ti-O bond to incorporate into the Ti-O cluster to form $\mathrm{SrTiO}_{3}{ }^{[31-33]}$. Since PEO film under LSCE could only provide a relatively low $\mathrm{Sr}$ concentration (Table S1) during $\mathrm{SrTiO}_{3}$ formation process, the $\left[\mathrm{Sr}(\mathrm{OH})_{x}\right]^{2-x}$ couldn't penetrate into the whole Ti-O sol. As a result, Ti-O prefers to exhibit a sheet-like morphology with insufficient incorporation of $\mathrm{Sr}$ and thus leads to the formation of non-stoichiometric $\mathrm{Sr}_{1-\delta} \mathrm{TiO}_{3}$ nanosheets. The condition is contrary in HSCE sample with a $\mathrm{Sr} / \mathrm{Ti}$ ratio of 0.79 . The increase of $\mathrm{Sr}$ concentration around HSCE sample can also lead to faster growth rate of $\mathrm{SrTiO}_{3}$ cube than that of $\mathrm{Sr}_{1-\delta} \mathrm{TiO}_{3}$ nanosheet, which is evidenced in SEM results (Fig. S4-S10).

The optical properties of $\mathrm{SrTiO}_{3}$ microcube and $\mathrm{Sr}_{1-\delta} \mathrm{TiO}_{3}$ nanosheets were roughly examined through a UV-Vis spectrometer. Fig. 6 shows the UV-Vis absorption spectra of PEO film and $\mathrm{SrTiO}_{3}$ samples synthesized under different conditions. It can be seen that the $\mathrm{SrTiO}_{3}$ microcube has only strong absorption around $390 \mathrm{~nm}$ with smaller inclination, while the $\mathrm{Sr}_{1-\delta} \mathrm{TiO}_{3}$ nanosheets show two absorption edges at around $335 \mathrm{~nm}$ and $400 \mathrm{~nm}$, respectively. Apparently, the $390 \mathrm{~nm}$ absorption is directly from $\mathrm{SrTiO}_{3}$ microcube, which corresponds to a band gap of $3.18 \mathrm{eV}$. For $\mathrm{Sr}_{1-\delta} \mathrm{TiO}_{3}$ nanosheets, the absorption edge located at around $335 \mathrm{~nm}$, which corresponds to a band gap of $3.71 \mathrm{eV}$, exhibits obvious blue-shift in comparison with the bulk $\mathrm{SrTiO}_{3}(3.25 \mathrm{eV})$ due to size effect ${ }^{[34-35]}$, while the $400 \mathrm{~nm}$ absorption edge can be attributed to the electron transition of rutile $\mathrm{TiO}_{2}$. In addition, the absorption intensity at $335 \mathrm{~nm}$ exhibts an increasing tendency along with the increase of $\mathrm{NaOH}$ concentration and soaking time, indicating more $\mathrm{Sr}_{1-\delta} \mathrm{TiO}_{3}$ nanosheets formed on the surface of PEO film. What's more, from the SEM images (Fig. S8-S10) of nanosheet samples, it can also be seen that the amount

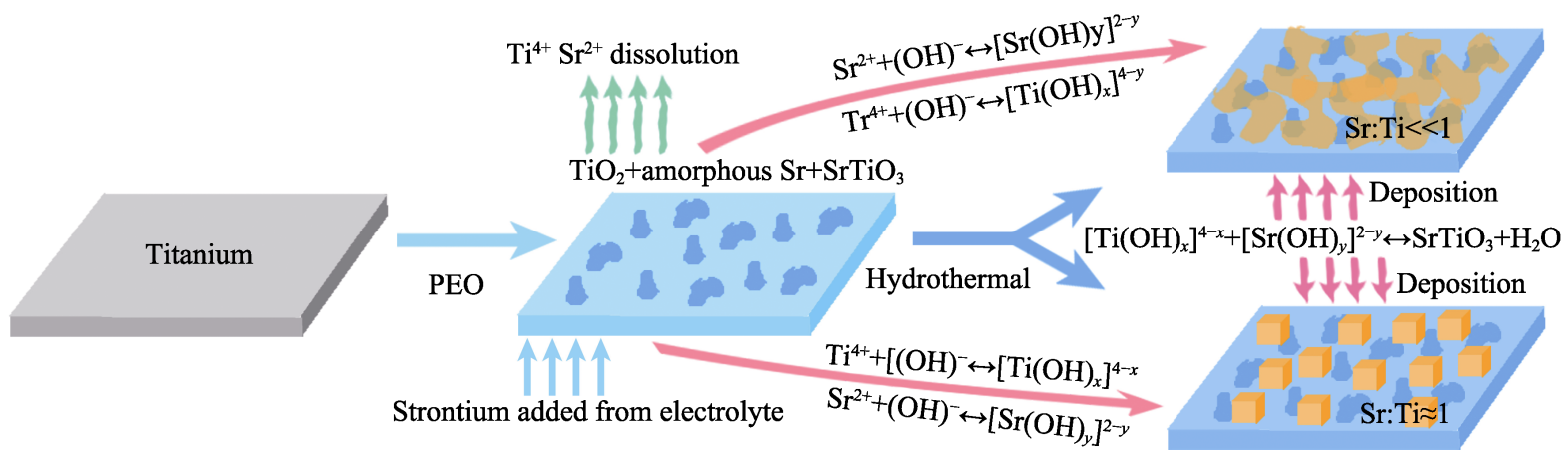

Fig. 5 Schematic diagram describing the formation process of $\mathrm{SrTiO}_{3}$ microcubes and $\mathrm{Sr}_{1-\delta} \mathrm{TiO}_{3}$ nanosheets 


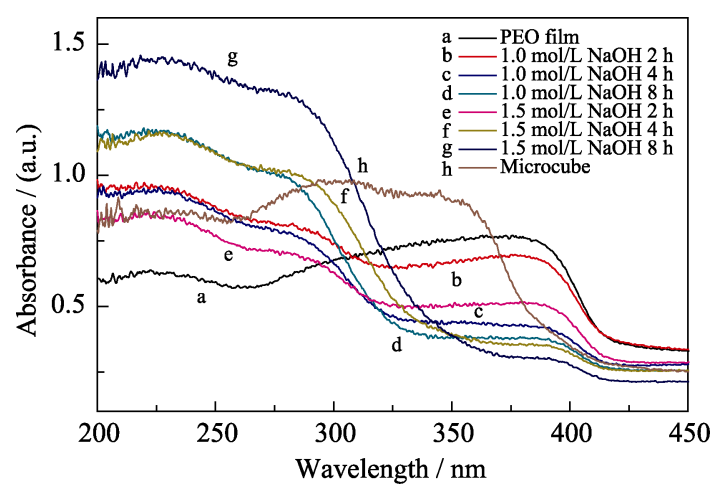

Fig. 6 UV-Vis spectra of $\mathrm{PEO}$ film, $\mathrm{SrTiO}_{3}$ microcubes and $\mathrm{Sr}_{1-\delta} \mathrm{TiO}_{3}$ nanosheets under different hydrothermal conditions

of nanosheets shows an increasing tendency along with the increase of $\mathrm{NaOH}$ concentration and soaking time. As a result, it can be concluded that the SEM results (Fig. S8-S10) and the UV-Vis absorption spectra of nanosheet sample strongly support the assertion that the nanosheets are mainly composed of $\mathrm{Sr}_{1-\delta} \mathrm{TiO}_{3}$. The difference of absorption features between $\mathrm{SrTiO}_{3}$ cubes and $\mathrm{Sr}_{1-\delta} \mathrm{TiO}_{3}$ nanosheets will provide more opportunities for promising applications in the fields of photocatalytic water-splitting, photocatalytic degradation and heterogeneous catalysis, etc.

\section{Conclusions}

$\mathrm{SrTiO}_{3}$ microcubes and $\mathrm{Sr}_{1-\delta} \mathrm{TiO}_{3}$ nanosheets have been in-situ fabricated on PEO film through a combined technology. The $\mathrm{SrTiO}_{3}$ microcubes obtained under HSCE show a regular cubic structure with (001) exposed crystal facets and superior crystalline quality without defects. Reducing the concentration of Sr source induces an obvious morphology evolution from microcubes to $\mathrm{Sr}_{1-\delta} \mathrm{TiO}_{3}$ nanosheets with a thickness of about several nanometers and (110) exposed facet. In addition, the two types of $\mathrm{SrTiO}_{3}$ nanostructures show significant difference in composition and optical absorption properties. $\mathrm{SrTiO}_{3}$ microcubes own a higher $\mathrm{Sr}$ concentration and a bulk-like optical absorption behavior, while $\mathrm{Sr}_{1-\delta} \mathrm{TiO}_{3}$ nanosheets with insufficient $\mathrm{Sr}$ content exhibit obvious blue-shift in optical absorption due to the size effect. It is believed that the initial $\mathrm{Sr} / \mathrm{Ti}$ atomic ratio in PEO film is mainly responsible for the morphology evolution of $\mathrm{SrTiO}_{3}$ nanostructures. This feasible in-situ synthetic strategy to $\mathrm{SrTiO}_{3}$ nanostructures with modified morphology, tunable band gap and optical properties will pave a solid way toward their promising application in the fields of photocatalysis for clean energy and environmental processing.

\section{References:}

[1] KAZIM S, NAZEERUDDIN M K, GRATZEL M, et al. Perovskite as light harvester: a game changer in photovoltaics. Angew Chem. Int. Edit., 2014, 53(11): 2812-2824.

[2] SULAEMAN U, YIN S, SATO T. Solvothermal synthesis and photocatalytic properties of chromium-doped $\mathrm{SrTiO}_{3}$ nanoparticles. Appl Catal B-Environ., 2011, 105(1/2): 206-210.

[3] IWASHINA K, KUDO A. Rh-doped $\mathrm{SrTiO}_{3}$ photocatalyst electrode showing cathodic photocurrent for water splitting under visiblelight irradiation. J. Am. Chem. Soc., 2011, 133(34): 13272-13275.

[4] COMES R B, SMOLIN S Y, KASPAR T C, et al. Visible light carrier generation in co-doped epitaxial titanate films. Appl. Phys. Lett., 2015, 106(9): 092901-1-5.

[5] PARK K I, XU S, LIU Y, et al. Piezoelectric $\mathrm{BaTiO}_{3}$ thin film nanogenerator on plastic substrates. Nano Letters, 2010, 10(12): 4939-4943.

[6] GRABOWSKA E. Selected perovskite oxides: characterization, preparation and photocatalytic properties-a review. Applied Catalysis B: Environmental, 2016, 186: 97-126.

[7] MADHAVAN B, ASHOK A. Review on nanoperovskites: materials, synthesis, and applications for proton and oxide ion conductivity. Ionics, 2014, 21(3): 1-10.

[8] KUDO A, MISEKI Y. Heterogeneous photocatalyst materials for water splitting. Chemical Society Reviews, 2009, 38(1): 253-278.

[9] DIAMANT Y, CHEN S G, MELAMED O, et al. Core-shell nanoporous electrode for dye sensitized solar cells: the effect of the $\mathrm{SrTiO}_{3}$ shell on the electronic properties of the $\mathrm{TiO}_{2}$ core. J. Phys. Chem. B, 2003, 107(9): 1977-1981.

[10] LENZMANN F, KRUEGER J, BURNSIDE S, et al. Surface photovoltage spectroscopy of dye-sensitized solar cells with $\mathrm{TiO}_{2}$, $\mathrm{Nb}_{2} \mathrm{O}_{5}$, and $\mathrm{SrTiO}_{3}$ nanocrystalline photoanodes: indication for electron injection from higher excited dye states. J. Phys. Chem. B, 2001, 105(27): 6347-6352.

[11] KANG Q, WANG T, LI P, et al. Photocatalytic reduction of carbon dioxide by hydrous hydrazine over $\mathrm{Au}-\mathrm{Cu}$ alloy nanoparticles supported on $\mathrm{SrTiO} / \mathrm{TiO}$ coaxial nanotube arrays. Angewandte Chemie International Edition, 2014, 54(3): 841-845.

[12] CAO T, LI Y, WANG C, et al. A facile in situ hydrothermal method to $\mathrm{SrTiO}_{3} / \mathrm{TiO}_{2}$ nanofiber heterostructures with high photocatalytic activity. Langmuir, 2011, 27(6): 2946-2952.

[13] LONG Z, WEI X H, QIU X Q. Preparation of $\mathrm{SrTiO}_{3}$ cubes by molten salt method and its surface ions modification with $\mathrm{Cu}(\mathrm{II})$ clusters. J. Inorg. Mater., 2013, 28(10): 1103-1107.

[14] ZHU Y R, TANG Y G, YAN J H, et al. Preparation and photocatalytic hydrogen generation activity of nitrogen doped $\mathrm{SrTiO}_{3}$ under visible light irradiation. J. Inorg. Mater., 2008, 23(3): 443-448.

[15] JI L, MCDANIEL M D, WANG S, et al. A silicon-based photocathode for water reduction with an epitaxial $\mathrm{SrTiO}_{3}$ protection layer and a nanostructured catalyst. Nat. Nano, 2014, 10(1): 84-90.

[16] YAN J H, ZHANG L, ZHU Y R, et al. Preparation and photocatalytic hydrogen production of $\mathrm{NiO}(\mathrm{CoO}) / \mathrm{N}-\mathrm{SrTiO}_{3}$ heterojunction complex catalyst under simulated sunlight irradiation. J. Inorg. Mater., 2009, 24(4): 666-670.

[17] KOVALEVSKY A V, POPUlOH S, PATRÍCIO S G, et al. Design of $\mathrm{SrTiO}_{3}$-based thermoelectrics by tungsten substitution. The Journal of Physical Chemistry C, 2015, 119(9): 4466-4478.

[18] OHTOMO A, HWANG H Y. A high-mobility electron gas at the $\mathrm{LaAlO}_{3} / \mathrm{SrTiO}_{3}$ heterointerface. Nature, 2004, 427(6973): 423426.

[19] KUANG Q, YANG S. Template synthesis of single-crystal-like porous $\mathrm{SrTiO}_{3}$ nanocube assemblies and their enhanced photocatalytic hydrogen evolution. ACS Applied Materials \& Interfaces, 2013, 5(9): 3683-3690.

[20] ZHAN H, CHEN Z G, ZHUANG J, et al. Correlation between 
multiple growth stages and photocatalysis of $\mathrm{SrTiO}_{3}$ nanocrystals. The Journal of Physical Chemistry C, 2015, 119(7): 3530-3537.

[21] SREEDHAR G, SIVANANTHAM A, BASKARAN T, et al. A role of lithiated sarcosine TFSI on the formation of single crystalline $\mathrm{SrTiO}_{3}$ nanocubes via hydrothermal method. Materials Letters, 2014, 133: 127-131.

[22] DONG L, LUO Q, CHENG K, et al. Facet-specific assembly of proteins on $\mathrm{SrTiO}_{3}$ polyhedral nanocrystals. Sci. Rep., 2014, 4: 5084-1-5.

[23] JIANG Y, LIU B, ZHAI Z, et al. A general strategy toward the rational synthesis of metal tungstate nanostructures using plasma electrolytic oxidation method. Appl. Surf. Sci., 2015, 356: 273-281.

[24] JIANG Y N, LIU B D, YANG W J, et al. New strategy for the in situ synthesis of single-crystalline $\mathrm{MnWO}_{4} / \mathrm{TiO}_{2}$ photocatalysts for efficient and cyclic photodegradation of organic pollutants. CrystEngComm., 2016, 18(10): 1832-1841.

[25] JIANG Y, LIU B, YANG L, et al. Size-controllable $\mathrm{Ni}_{5} \mathrm{TiO}_{7}$ nanowires as promising catalysts for CO oxidation. Sci. Rep., 2015, 5: 14330-1-10.

[26] JIANG Y, LIU B, YANG W, et al. Crystalline $\left(\mathrm{Ni}_{1-x} \mathrm{Co}_{x}\right)_{5} \mathrm{TiO}_{7}$ nanostructures grown in situ on a flexible metal substrate used towards efficient CO oxidation. Nanoscale, 2017, 9(32): 11713-11719.

[27] JIANG X, ZHANG L, WYBORNOV S, et al. Highly efficient nanoarchitectured $\mathrm{Ni}_{5} \mathrm{TiO}_{7}$ catalyst for biomass gasification. ACS Applied Materials \& Interfaces, 2012, 4(8): 4062-4066.

[28] BARATI N, YEROKHIN A, GOLESTANIFARD F, et al. Aluminazirconia coatings produced by plasma electrolytic oxidation on $\mathrm{Al}$ alloy for corrosion resistance improvement. J. Alloy Compd., 2017, 724: 435-442.

[29] HAASCH R T, BRECKENFELD E, MARTIN L W. Single crystal perovskites analyzed using X-ray photoelectron spectroscopy: 1. $\mathrm{SrTiO}_{3}(001)$. Surface Science Spectra, 2014, 21(1): 87-94.

[30] MOCKEL H, GIERSIG M, WILLIG F. Formation of uniform size anatase nanocrystals from bis(ammoniumlactato)titanium dihydroxide by thermohydrolysis. Journal of Materials Chemistry, 1999, 9(12): 3051-3056.

[31] KATO K, DANG F, MIMURA K I, et al. Nano-sized cube-shaped single crystalline oxides and their potentials, composition, assembly and functions. Advanced Powder Technology, 2014, 25(5): 1401-1414.

[32] FUJINAMI K, KATAGIRI K, KAMIYA J, et al. Sub-10 nm strontium titanate nanocubes highly dispersed in non-polar organic solvents. Nanoscale, 2010, 2(10): 2080-2083.

[33] GUO Y, LIU G, REN Z, et al. Single crystalline brookite titanium dioxide nanorod arrays rooted on ceramic monoliths: a hybrid nanocatalyst support with ultra-high surface area and thermal stability. CrystEngComm., 2013, 15(41): 8345-8352.

[34] AKKERMAN Q A, MOTTI S G, KANDADA A R S, et al. Solution synthesis approach to colloidal cesium lead halide perovskite nanoplatelets with monolayer-level thickness control. J. Am. Chem. Soc., 2016, 138(3): 1010-1016.

[35] XU Z T, MITZI D B, DIMITRAKOPOUlOS C D, et al. Semiconducting perovskites $\left(2-\mathrm{XC}_{6} \mathrm{H}_{4} \mathrm{C}_{2} \mathrm{H}_{4} \mathrm{NH}_{3}\right)_{2} \mathrm{SnI}_{4}(\mathrm{X}=\mathrm{F}, \mathrm{Cl}, \mathrm{Br})$ : steric interaction between the organic and inorganic layers. Inorganic Chemistry, 2003, 42(6): 2031-2039.

\title{
形貌可控及光学吸收性能可调的钙钛矿型 $\mathrm{SrTiO}_{3}$ 纳米结构的原位生长
}

\author{
刘小元 ${ }^{1,2}$, 刘宝丹 ${ }^{1}$, 姜亚南 ${ }^{1}$, 王 柯 ${ }^{1,2}$, \\ 周 洋 ${ }^{1,2}$, 杨 兵 $^{1}$, 张兴来 ${ }^{1}$, 姜 辛 $^{1}$
}

(1. 中国科学院 金属研究所, 沈阳材料科学国家研究中心, 沈阳 110016；2. 中国科学技术大学 材料科学与工程 学院, 合肥 230026)

摘 要: 钙钛矿相 $\mathrm{SrTiO}_{3}$ 在太阳能电池、光催化、燃料电池, 超导等领域均有广泛应用, 这些应用均与其晶体质量、 形貌、暴露晶面和光学吸收等特性息息相关。本文通过微弧氧化-水热两步法原位制备了两种典型形貌的 $\mathrm{SrTiO}_{3}$ 纳米晶。结果表明, 随着微弧氧化电解液锶源浓度的降低, $\mathrm{SrTiO}_{3}$ 形貌从立方块状转变为超薄片状。进一步分析表 明, 所得的 $\mathrm{SrTiO}_{3}$ 立方块和 $\mathrm{Sr}_{1-\delta} \mathrm{TiO}_{3}$ 纳米片均为结晶质量良好的单晶体, 通过分析两种形貌样品的紫外-可见漫反 射光谱, 发现 $\mathrm{Sr}_{1-\delta} \mathrm{TiO}_{3}$ 纳米片相对于 $\mathrm{SrTiO}_{3}$ 立方块, 具有明显的尺寸效应诱导的光学吸收蓝移特性。最后, 本研究 提出了 $\mathrm{SrTiO}_{3}$ 的原位生长及形貌演变机制。

关 键 词: 钛酸锶; 原位生长; 微弧氧化法; 形貌调控; 光学性能 中图分类号: TQ174 文献标识码: A 
Supporting information

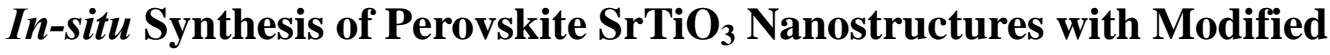 Morphology and Tunable Optical Absorption Property
}

\author{
LIU Xiao-Yuan ${ }^{1,2}$, LIU Bao-Dan ${ }^{1}$, JIANG Ya-Nan ${ }^{1}$, WANG Ke ${ }^{1,2}$, ZHOU Yang ${ }^{1,2}$, \\ YANG Bing ${ }^{1}$, ZHANG Xing-Lai ${ }^{1}$, JIANG Xin ${ }^{1}$
}

(1. Shenyang National Laboratory for Materials Science, Institute of Metal Research, Chinese Academy of Sciences, Shenyang 110016, China; 2. School of Materials Science and Engineering, University of Science and Technology of China, Hefei 230026, China)
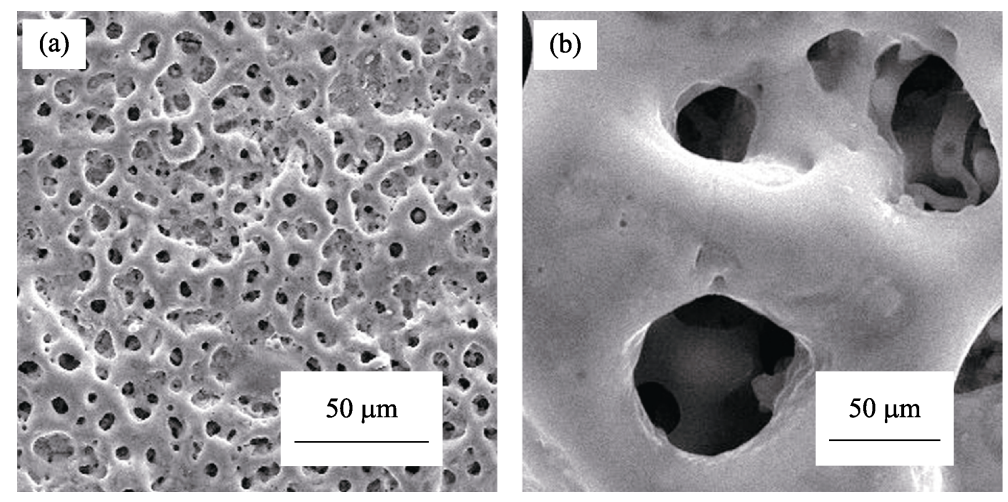

Fig. S1 SEM images of PEO film
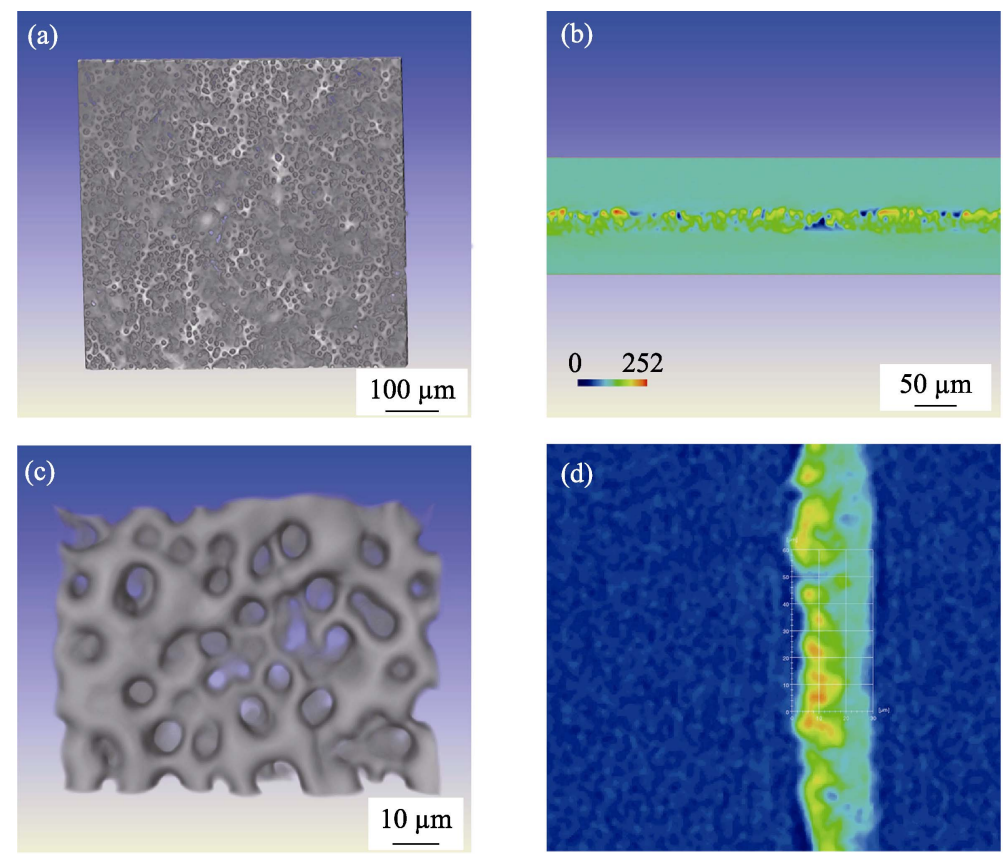

Fig. S2 (a, c) X-ray diffraction topography (XRT) images of PEO film surface morphology and (b, d) cross section images

Table S1 EDS results of PEO film prepared in high Sr concentration electrolyte (HSCE) and low Sr concentration electrolyte (LSCE)

\begin{tabular}{ccccc}
\hline Sample & O/at $\%$ & Ti/at $\%$ & Sr/at $\%$ & $n(\mathrm{Sr}): n(\mathrm{Ti})$ \\
\hline HSCE & 79.35 & 11.51 & 9.14 & 0.79 \\
LSCE & 53.93 & 37.32 & 8.75 & 0.23 \\
\hline
\end{tabular}


Table S2 EDS results of $\mathrm{SrTiO}_{3}$ microcubes and $\mathrm{Sr}_{1-\delta} \mathrm{TiO}_{3}$ nanosheets

\begin{tabular}{ccccc}
\hline Sample & $\mathrm{O} / \mathrm{at} \%$ & $\mathrm{Ti} / \mathrm{at} \%$ & $\mathrm{Sr} / \mathrm{at} \%$ & $n(\mathrm{Sr}): n(\mathrm{Ti})$ \\
\hline Microcube & 55.06 & 24.16 & 20.77 & 0.86 \\
Nanosheet & 61.65 & 31.65 & 6.7 & 0.21 \\
\hline
\end{tabular}

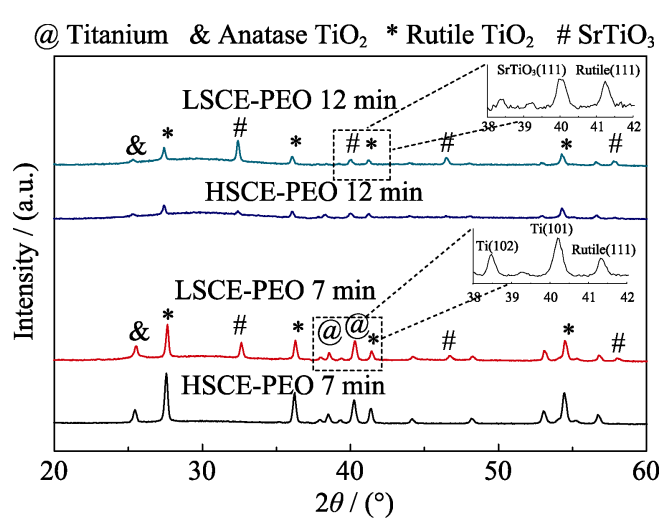

Fig. S3 XRD patterns of PEO films prepared under different conditions

LSCE, 7 min PEO treating time; LSCE, 12 min PEO treating time, HSCE, 7 min PEO treating time and HSCE, 12 min PEO treating time
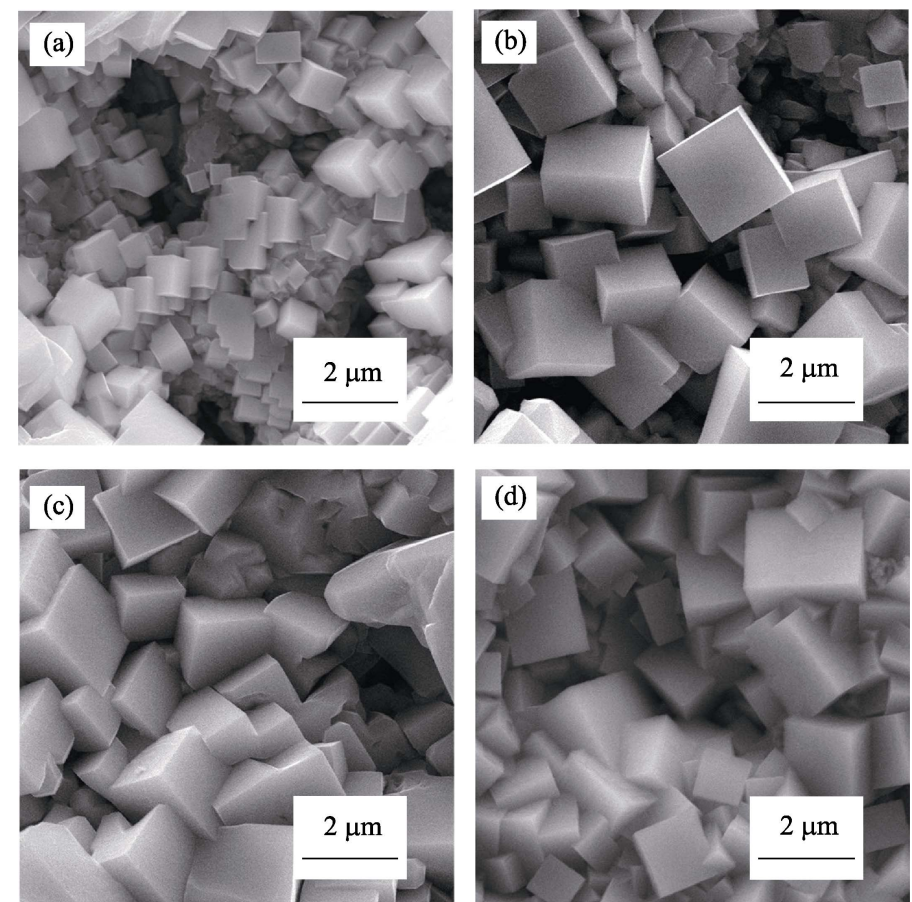

Fig. S4 SEM images of $\mathrm{SrTiO}_{3}$ microcubes obtained on PEO film under HSCE and in $0.5 \mathrm{~mol} / \mathrm{L} \mathrm{NaOH}$ with different durations (a) $180^{\circ} \mathrm{C}, 1 \mathrm{~h}$; (b) $180^{\circ} \mathrm{C}, 4 \mathrm{~h}$; (c) $180^{\circ} \mathrm{C}, 6 \mathrm{~h}$; (d) $180^{\circ} \mathrm{C}, 8 \mathrm{~h}$

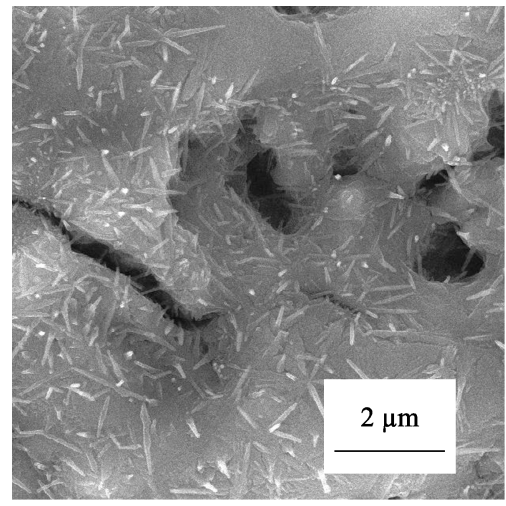

Fig. S5 Surface morphology of PEO film after hydrothermal treating (without $\mathrm{NaOH}, 180^{\circ} \mathrm{C}, 8 \mathrm{~h}$ ) 
Table S3 XPS element analysis of $\mathrm{Sr}_{1-\delta} \mathrm{TiO}_{3}$ nanosheets

\begin{tabular}{cccccc}
\hline Sample & $\mathrm{O} / \mathrm{at} \%$ & $\mathrm{~B} / \mathrm{at} \%$ & $\mathrm{Ti} / \mathrm{at} \%$ & $\mathrm{Sr} / \mathrm{at} \%$ & $n(\mathrm{Sr}): n(\mathrm{Ti})$ \\
\hline Nanosheet & 69.95 & 0.70 & 22.39 & 6.96 & 0.31 \\
\hline
\end{tabular}
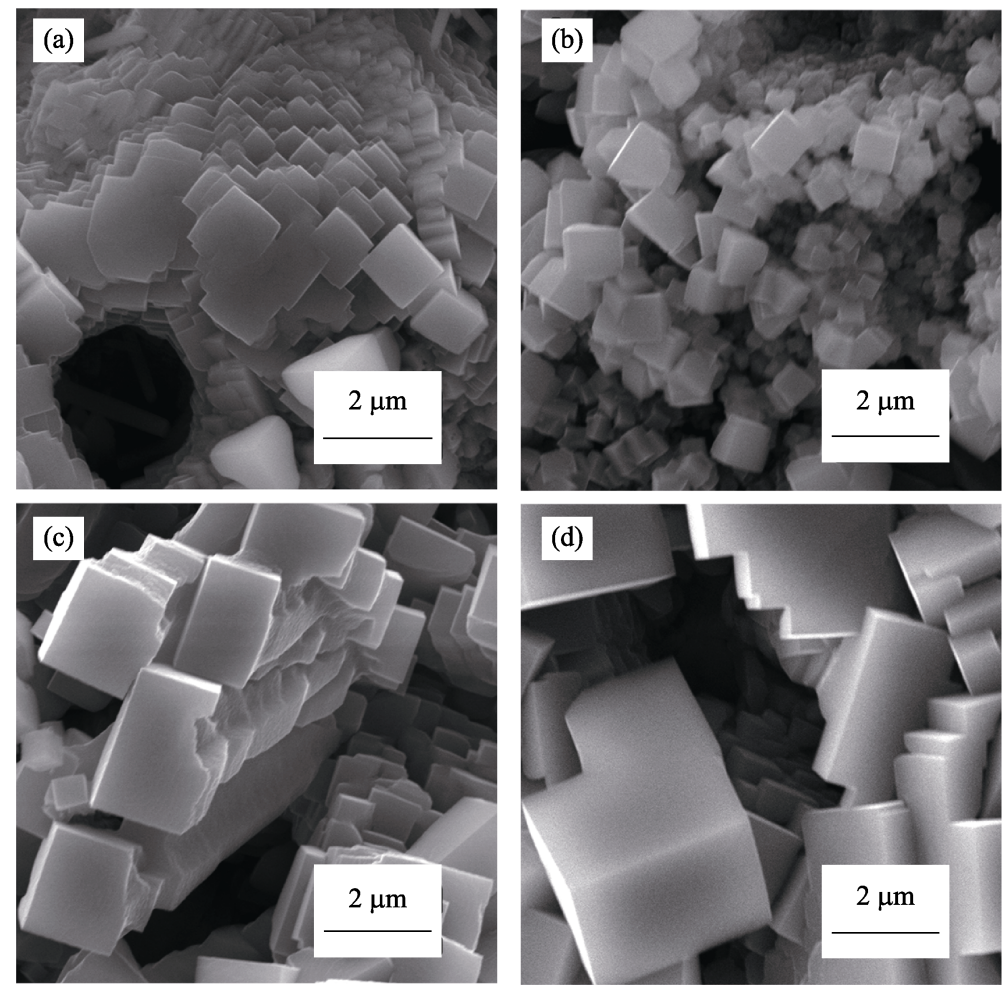

Fig. S6 SEM images of $\mathrm{SrTiO}_{3}$ microcubes obtained on PEO film under $\mathrm{HSCE}$ and in $1.0 \mathrm{~mol} / \mathrm{L} \mathrm{NaOH}$ with different durations (a) $180^{\circ} \mathrm{C}, 0.5 \mathrm{~h}$; (b) $180^{\circ} \mathrm{C}, 1 \mathrm{~h}$; (c) $180^{\circ} \mathrm{C}, 2 \mathrm{~h}$; (d) $180^{\circ} \mathrm{C}, 8 \mathrm{~h}$
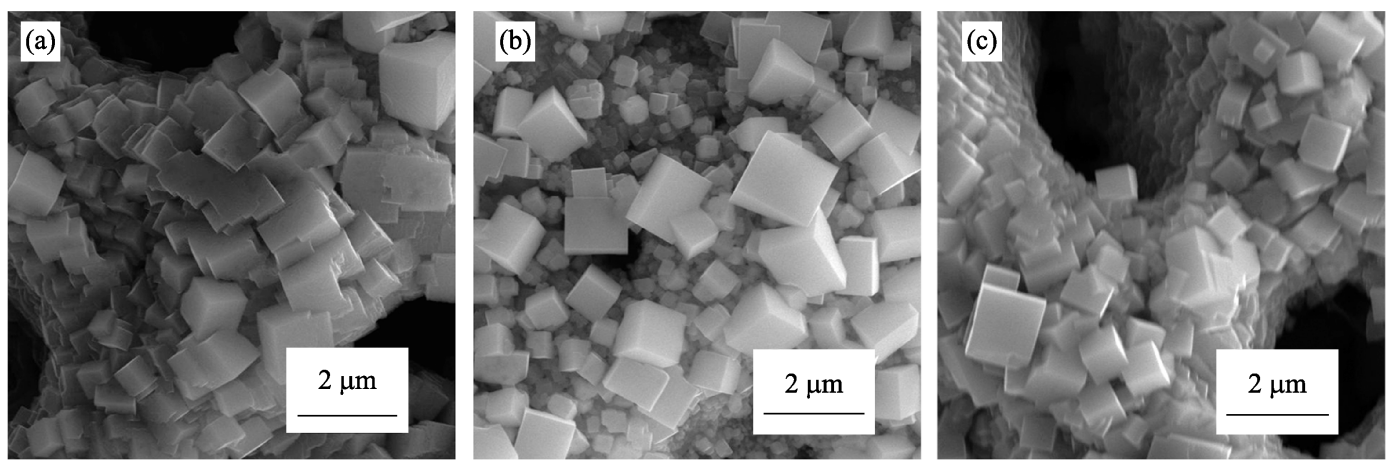

Fig. S7 SEM images of $\mathrm{SrTiO}_{3}$ microcubes obtained on PEO film under $\mathrm{HSCE}$ and in $1.5 \mathrm{~mol} / \mathrm{L} \mathrm{NaOH}$ with different durations (a) $180^{\circ} \mathrm{C}, 4 \mathrm{~h} ;$ (b) $180^{\circ} \mathrm{C}, 6 \mathrm{~h} ;$ (c) $180^{\circ} \mathrm{C}, 8 \mathrm{~h}$ 

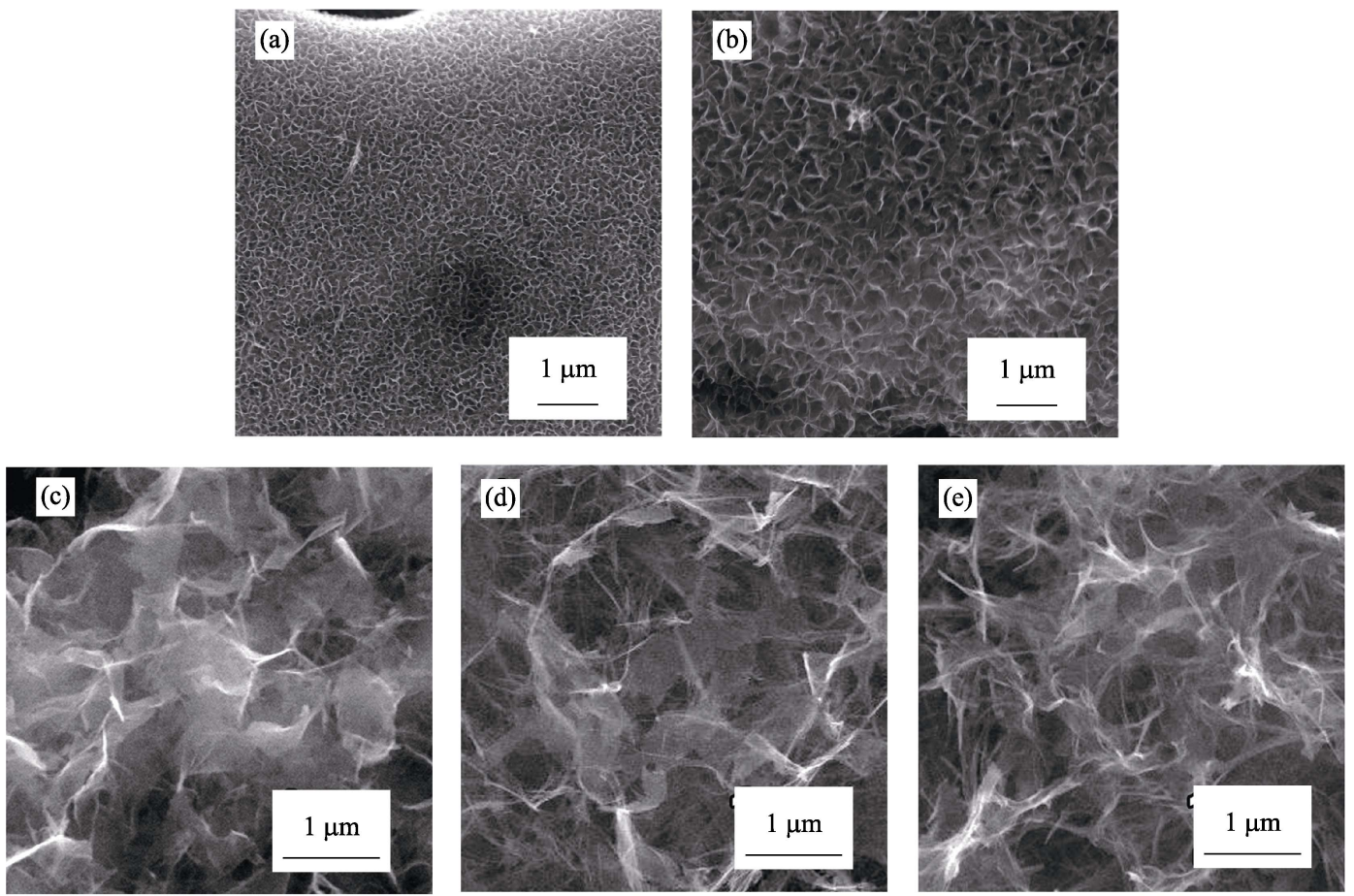

Fig. S8 SEM images of $\mathrm{Sr}_{1-\delta} \mathrm{TiO}_{3}$ nanosheets obtained on PEO film under LSCE and in $1.0 \mathrm{~mol} / \mathrm{L} \mathrm{NaOH}$ with different durations (a) $180^{\circ} \mathrm{C}, 0.5 \mathrm{~h}$; (b) $180^{\circ} \mathrm{C}, 1 \mathrm{~h}$; (c) $180^{\circ} \mathrm{C}, 2 \mathrm{~h}$; (d) $180^{\circ} \mathrm{C}, 4 \mathrm{~h}$; (e) $180^{\circ} \mathrm{C}, 8 \mathrm{~h}$
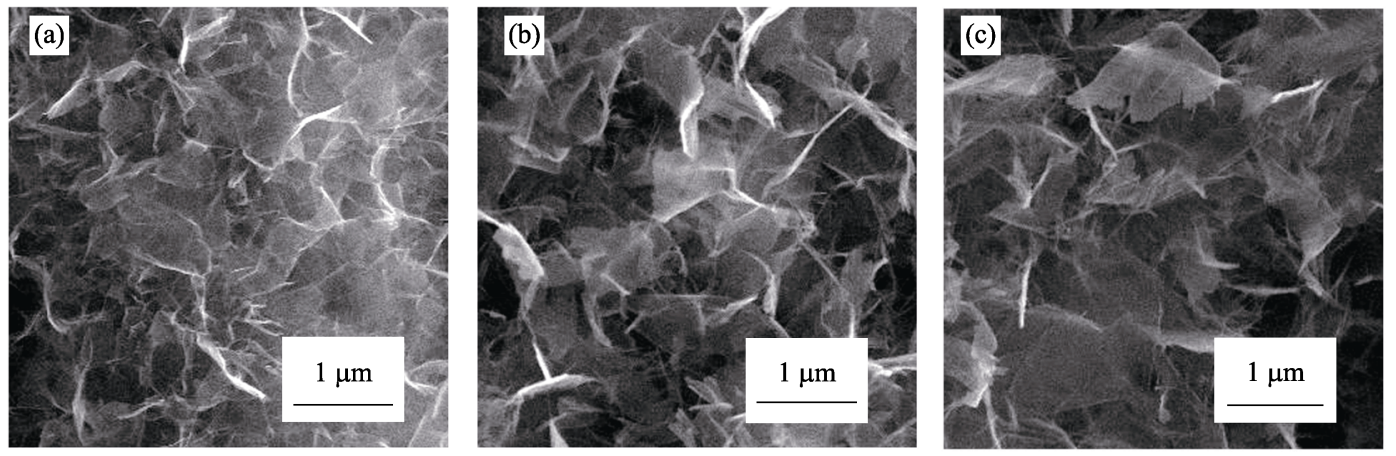

Fig. S9 SEM images of $\mathrm{Sr}_{1-\delta} \mathrm{TiO}_{3}$ nanosheets obtained on PEO film under LSCE and in $0.5 \mathrm{~mol} / \mathrm{L} \mathrm{NaOH}$ with different durations (a) $180^{\circ} \mathrm{C}, 2 \mathrm{~h}$; (b) $180^{\circ} \mathrm{C}, 4 \mathrm{~h}$; (c) $180^{\circ} \mathrm{C}, 8 \mathrm{~h}$
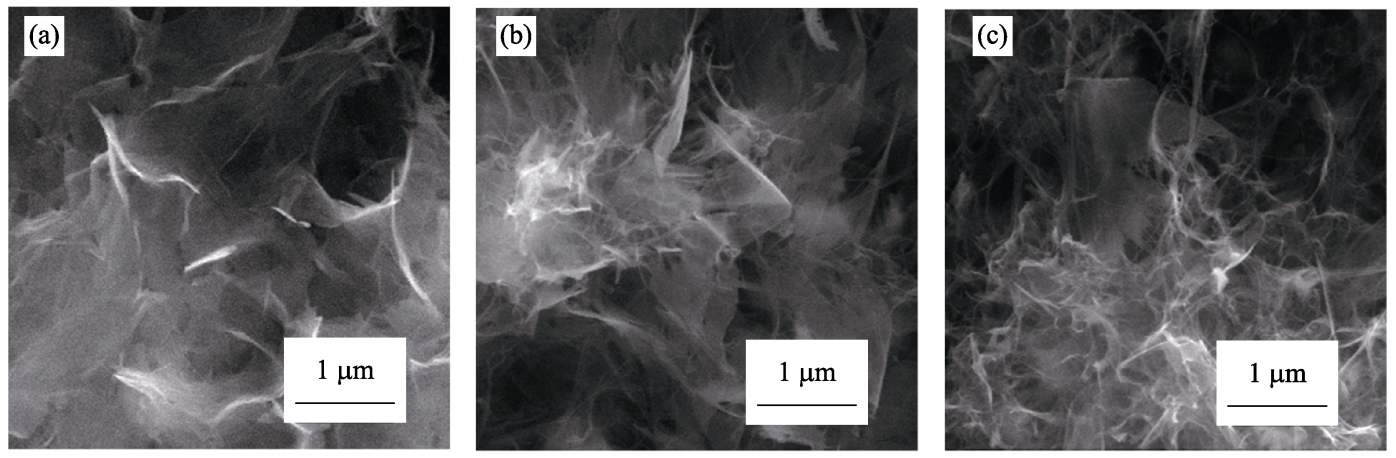

Fig. S10 SEM images of $\mathrm{Sr}_{1-\delta} \mathrm{TiO}_{3}$ nanosheets obtained on PEO film under LSCE and in $1.5 \mathrm{~mol} / \mathrm{L}$ NaOH with different durations (a) $180^{\circ} \mathrm{C}, 2 \mathrm{~h}$; (b) $180^{\circ} \mathrm{C}, 4 \mathrm{~h}$; (c) $180^{\circ} \mathrm{C}, 8 \mathrm{~h}$ 